\title{
Podometry and mineral content in hooves of Campeiro horses
}

\author{
Anderson F. de Souza', Rubens P. Mendes', Jackson Schade', Rogério Laus², Marcelo A. Moreira², Thiago R. Muller and Joandes H. \\ Fontequel \\ 1 Department of Veterinary Medicine, Agroveterinary Sciences Center (CAV), Santa Catarina State University (UDESC), Lages, SC, Brazil \\ 2 Department of Soils and Natural Resources, Agroveterinary Sciences Center (CAV), Santa Catarina State University (UDESC), Lages, SC, Brazil
}

\begin{abstract}
Summary: The Campeiro horses descend from animals brought into southern Brazil by Spaniards between the sixteenth and seventeenth centuries. They have shown adaptations to local climatic conditions, types of feeding, management, and selection models to which they have been exposed over the years. This study aims to investigate the characteristics of hooves of the Campeiro horse by means of morphometry and measurement of the contents of some minerals and propose an approach to assess the balance of the palmar/plantar region of the hooves. Hoof morphometry data from the fore and hind hooves of 50 horses were recorded. The mediolateral balance of hooves was assessed by the symmetry of heels, assessing their vertical, linear, and angular metrics. Contents of $\mathrm{Ca}, \mathrm{Mg}, \mathrm{Cu}, \mathrm{Fe}$, and $\mathrm{Zn}$ were measured by atomic absorption spectrophotometry, while K and Na levels were measured by atomic emission in sole, wall and frog. Forelimbs showed longer and wider hooves and longer frog. Toe angle was higher in hindlimbs, while the ratio body mass/hoof-ground contact area was similar between the limbs. High frequency of frog contraction (40.4\%), angular imbalance of heels (differences greater than five degrees between lateral and medial heels) (30.3\%) and underrun heels (82.7\%) was observed. Regardless of pigmentation, hoof contents of $\mathrm{Cu}, \mathrm{Fe}$, and $\mathrm{Zn}$ were higher in the wall, while K, Ca, and Mg levels were greater in the frog. Pigmented hooves (dark) had higher levels of Fe in the wall and sole and higher levels of $\mathrm{K}$ in the sole and frog compared to the non-pigmented hooves (light). We can infer that indirect measures of hoof height and palmar/plantar region were adequate. Furthermore, differences in the content of some minerals between dark and light hooves did not reflect on differences in quality.
\end{abstract}

Keywords: Campeiro horse, hoof balance, trimming, shoeing, lameness, mineral content

Citation: Souza A. F., Mendes R. P., Schade J., Laus R., Moreira M. A., Muller T. R., Fonteque J. H. (2020) Podometry and mineral content in hooves of Campeiro horses. Pferdeheilkunde 37, 56-64; DOI 10.21836/PEM20210108

Correspondence: Anderson Fernando de Souza, Agroveterinary Sciences Center (CAV), Santa Catarina State University (UDESC), Lages, SC, Brazil. Av. Luiz de Camões, 2090, Conta Dinheiro, Lages, SC, Brazil, 88520-000; anderson.sji@hotmail.com

Submitted: August 20, 2020 | Accepted: September 9, 2020

\section{Introduction}

The Campeiro horses descend from animals brought into southern Brazil by Spaniards between the sixteenth and seventeenth centuries (Solano et al. 2013). These horses have shown adaptations to local climatic conditions, types of feeding, management, and selection models to which have been exposed over the years, noted in studies of some of its biological characteristics (Souza et al. 2019, Souza et al. 2016b, Fonteque et al. 2016).

Its main characteristic is that it is a gaited horse, which makes these animals very comfortable when riding. For this reason, they are widely used to ride and cattle management (Souza et al. 2018). The natural conditions in which the entire process of formation of the Campeiro horse occurred is still a reality in many breeders, where the animals are kept in natural fields, composed of grasses, which predominate species of Aristida, Andropogon, Schizachyrium, Elyonurus, and Trachypogon (Souza et al. 2018, Falcão 2002, Mariante 2000).

In this sense the characteristics of the hooves of this breed have not been studied yet. There is consensus amongst hoof care professionals that hoof morphology is affected by environmental and management conditions including work type and intensity (Souza et al. 2016a, Hampson et al. 2010, Nicoletti et al. 2000). Knowledge of an understanding of both balance matrix is essential for accurate diagnosis and treatment of foot related pathologies (Souza et al. 2016a, Ornicek et al. 2003).

However, the current study of the palmar/plantar region of the equine hoof are still scarce (Hunt 2012). This generates technical-scientific knowledge that can be implemented in breeding and selection, seeking an improved animal with a genuine identity of the Campeiro horse (Souza et al. 2018), furthermore, it may be possible to apply these findings to the general riding horse population.

The role of minerals in keratinized hoof tissue formation has been more studied in dairy cattle than in horses. Calcium, copper, zinc, and magnesium are essential to avoid problems in hooves (Johnson and Schugel 1994). Bragulla et al. (1999) clarified the importance of minerals in activating enzymes involved in keratinization of horn cells. It seems reasonable to assume that mineral deficiencies can induce structural changes in hooves and, therefore, serve as a parameter to evaluate 
the health and integrity of this tissue. Nevertheless, deficiency states are identified by comparison with reference data, which are scarce in the literature.

This study aims to characterise hoof metrics and recognise differences in palmar/planter region in addition to measuring the content of essential minerals including $\mathrm{Ca}, \mathrm{Mg}, \mathrm{Cu}$, $\mathrm{Fe}, \mathrm{Zn}, \mathrm{Na}$ and $\mathrm{K}$ contents in hooves of Campeiro horses, In addition to identifying differences between pigmented and non pigmented horn and on different regions (wall, sole, and frog).

\section{Materials and Methods}

Animals

The hoof metric data of the front and hind hooves from 50 Campeiro horses were taken. Animals had average age and body mass of $10.8 \pm 7.0$ years and $411.7 \pm 46.4 \mathrm{~kg}$, respectively. Among them, 42 females (84\%) and eight males (16\%) were included, and all of them were registered in the Brazilian Association of Campeiro Horse Breeders (ABRACCC). The horses came from six in-situ conservation farms located in the cities of Lages, Curitibanos, and Concordia (Santa Catarina state), and from São Francisco de Paula and Caxias do Sul (Rio Grande do Sul state), southern Brazil. All of them were maintained in a semi-extensive management system and fed native pasture and/or ryegrass and Tifton grasses, mineral salt, commercial concentrated feed (14\% crude protein), and water ad libitum. Body mass was estimated using a weight tape, which makes a correlation between body mass and thoracic perimeter. Animals that presented complains of lameness were excluded from the study. A complete examination of the locomotor system was not performed. All the animals included in the study had been unshod for at least 60 days. The form and frequency of past hoof management was not considered in this study.

\section{Podometry}

To avoid variations, a single trained professional performed all measurements, with the animal contained with halter in flat surface. Measures were taken with the raised limb. Hooves were directly measured according to the procedures of Turner (1992), Lazzeri (1992), Melo et al. (2006), and Nicoletti et al. (2000), using a caliper ruler, tape measure, and hoof gauge ${ }^{l}$, and indirectly using trigonometric equations. Directly measured parameters were frog length and width, medial and lateral heel length and angle, toe length and angle, hoof width and length, and coronet circumference. While the indirectly measured ones were hoof height, and medial and lateral heel heights, which were obtained by applying the following equations proposed by the authors of this study, respectively:

$$
\mathrm{Hh}=\mathrm{SIN} \alpha \mathrm{T} \times \mathrm{TI}
$$$$
\mathrm{Hhl}(\mathrm{m})=\operatorname{SIN} \alpha \mathrm{TI}(\mathrm{m}) \times \mathrm{LHI}(\mathrm{m})
$$

$\mathrm{Hh}$, hoof height; SIN, sine; $\alpha \mathrm{T}$, toe angle; Tl, toe length; $\mathrm{Hhl}$ $(\mathrm{m})$, height of the lateral or medial heel; $\alpha \mathrm{HI}(\mathrm{m})$, angle of the lateral or medial heel; LHI (m), length of the lateral or medial heel. The hoof height was determined by multiplying the sine of the toe angle by the toe length. The height of the medial or lateral heel was measured by multiplying the sine of the heel angle by the heel length in ipsilateral limbs.

The ratio between body mass and hoof area was calculated using the following formula: [body mass $(\mathrm{kg}) \times 12.56] /[$ coronet circumference $\left.{ }^{2}(\mathrm{~cm})\right]$, hooves presenting with a size to body mass ratio of $5.5 \mathrm{~kg} / \mathrm{cm}^{2}$ were considered small (Turner 2003). This formula is a junction of the mathematical formulas of the circumference $(2 \pi r)$ and area $\left(\pi r^{2}\right)$ of a circle in which the coronet circumference is measured, and including the body mass, it gives the approximate area of a circle (hoof solar surface) that supports a certain loadThe ratio between the length and width of frog was defined according to Turner (2003), wherein the width should not be less than $2 / 3$ of its length; otherwise, it was classified as contracted. Underrun heels were deemed present in hooves when the differences between toe angle and palmar/plantar region angle were encountered, which was measured by the mean of the medial and lateral heel angles that were equal to or greater than five degrees (Turner 1986).

Medial-lateral hoof balance was evaluated by measuring the symmetry of heels using three parameters: (i) heel vertical imbalance: defined as differences equal to or greater than $0.5 \mathrm{~cm}$ between the heights of lateral and medial heels, as cited previously (Melo et al. 2006); (ii) heel linear imbalance: defined as differences equal to or greater than $0.5 \mathrm{~cm}$ between the lengths of lateral and medial heels, as previously described (Turner 1992); (iii) heel angular imbalance: defined as differences equal to or greater than five degrees between the angles of lateral and medial heels. We proposed such magnitude of difference based on several studies that have evaluated the effects of angular changes in hooves on locomotion biomechanics (Back et al. 2003, Crevier-Denoix et al. 2001, Hinterhofer et al. 2000, Wilson et al. 1998). Figure 1 shows reference points for the distances obtained in heel balance evaluation and the point considered for hoof height.

\section{Mineral analysis}

Thirty of the horses used in the podometry were selected for sampling, 23 females (77\%) and seven males (23\%) $(414.3 \pm 46.1 \mathrm{~kg}$ and $10.9 \pm 7.6$ years). The samples were collected from hoof wall, sole, and frog using of hoof nipper and hoof knife, distinguishing between pigmented (dark) and unpigmented (light) hooves. These samples were washed with mineral-free detergent (Extram) and distilled water, then dried with absolute alcohol, packed in sealed plastic bags, and frozen until analysis.

Aliquots $(0.3 \mathrm{~g})$ from the sample pool of each animal was digested in $6.0 \mathrm{ml} \mathrm{HNO}_{3}$ PA solution in a microwave ${ }^{2}$, diluted to $30 \mathrm{~mL}$ with distilled water (conductivity $<5 \mu \mathrm{S} / \mathrm{cm}$ ), packed in $50 \mathrm{ml}$ Falcon tubes, and refrigerated. The contents of $\mathrm{Ca}$, $\mathrm{Mg}, \mathrm{Cu}, \mathrm{Fe}$, and $\mathrm{Zn}$ were determined by flame atomic absorption spectrophotometry ${ }^{3}$. While the levels of $\mathrm{K}$ and $\mathrm{Na}$ were determined by atomic emission, using a flame photometer ${ }^{4}$. A $1 \%$ lanthanum solution was added to a standard Ca solution and to the samples for $\mathrm{P}$ complex formation, thus, leaving $\mathrm{Ca}$ free for analysis (Tedesco et al. 1995). 


\section{Statistical analysis}

Data normality was assessed by the Kolmogorov-Smirnov's test. The means of biometric values between fore and hindlimbs and the means of mineral contents between dark and light hooves were compared by either the T-test or the Mann-Whitney's test. An analysis of variance (ANOVA) followed by Tukey's test was used for means of body mass, hoof area between limbs, and for mineral contents at different hoof parts. All the values at $p<0.05$ were considered significant. A Pearson's correlation was applied to evaluate body mass versus toe length and versus coronet circumference, both measured in the left forelimb. The origin of the animals was not considered as a source of variation, due to similarities of the farms.

\section{Results}

In most of the animals evaluated, the hooves presented, on inspection, reasonable conformation, with good wall thickness and the frog with a healthy aspect. Longitudinal fissures and irregular transverse lines were rarely seen. The white line is generally intact. When trimming, we observed good resistance and due to the absence of nails, dark areas typical of shoeing horses were not noticed.

Table 1 presents the means and standard deviations of 15 hoof measurements. The comparison of hoof conformation between thoracic and pelvic limbs showed longer $(p=0.0424)$ and wider $(p=0.0126)$ front hooves, and longer frog $(p=0.0341)$. The ratio between body mass and hoof area showed values within the range deemed appropriate, regardless of which limb was used to measure coronet circumference ( $p>0.05)$. Additionally, the correlation between body mass and toe length was weak (0.13), whereas between body mass and coronet circumference was moderate $(0.64)$.

Table 2 presents the assessment of hoof imbalances. The results showed that the evaluated samples had high rates of frog contraction, heel angular imbalance, and underrun heels. Forelimbs accounted for $73.8 \%$ (59/80) of frog contractions, and hindlimbs for $58.3 \%$ (35/60) of heel angular imbalances. The frequency of underrun heels was similar in both limbs. In addition, no hoof was classified as small.

Table 3 shows the frequency of the combined heel imbalances, being grouped the imbalances indicated in the columns of the table were simultaneously present. Hooves presenting vertical imbalance associated with angular imbalance were the most prevalent among the observations. The concomitant presence of the three types of imbalances in the same hoof was rare. Figure 2 shows the angular differences between the toe and heel, which characterize underrun heels.

Table 4 exhibits the concentrations of elements for each hoof area, regardless of tissue pigmentation. $\mathrm{Cu}, \mathrm{Fe}$, and $\mathrm{Zn}$ contents were higher in the hoof wall, while $\mathrm{K}, \mathrm{Ca}$, and $\mathrm{Mg}$ contents were greater in the frog. Table 5 discriminates the concentrations of elements between light and dark hooves. Dark hooves presented higher levels of Fe in wall and sole, whereas those of $\mathrm{K}$ were in sola and frog. In dark hooves, the highest levels of $\mathrm{Cu}, \mathrm{Fe}$, and $\mathrm{Zn}$ were in the wall, while the highest contents of $\mathrm{Ca}$ and $\mathrm{Mg}$ were in the frog. In light hooves, higher levels of $\mathrm{Zn}$ were found in the wall, whereas those of $\mathrm{K}$ and Ca were in the frog. In general, lower levels of Fe were found in the soles.

\section{Discussion}

\section{Podometry}

Our data on hoof conformation for Campeiro horses were similar to those of other horse species (Souza et al. 2016a, Dau et al. 2015, Schade et al. 2013, Nicoletti et al. 2000). This result is evidenced by the differences in hooves between the fore and hindlimbs, where the hooves of forelimbs were wider, longer, and more rounded than the hindlimbs, as described by Stachurska et al. (2008).

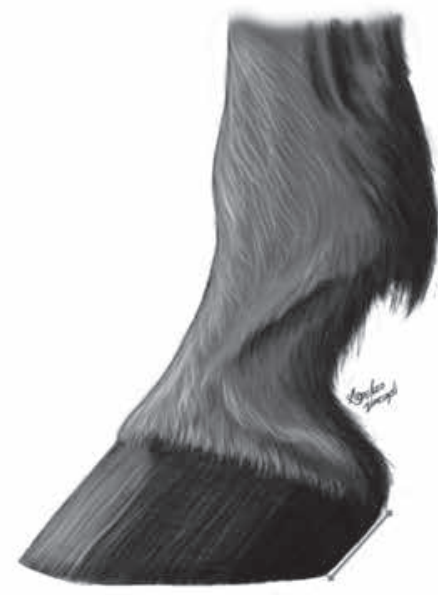

A

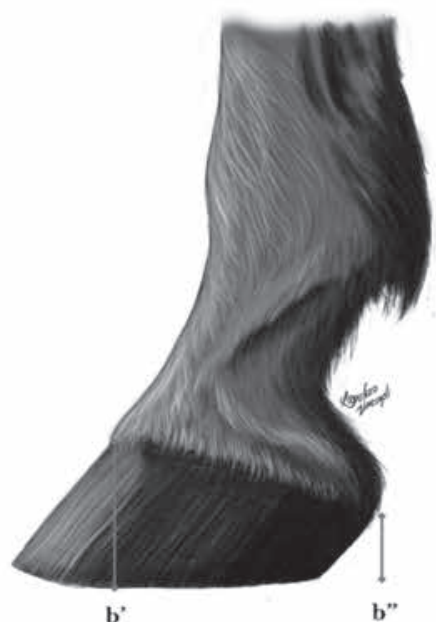

B

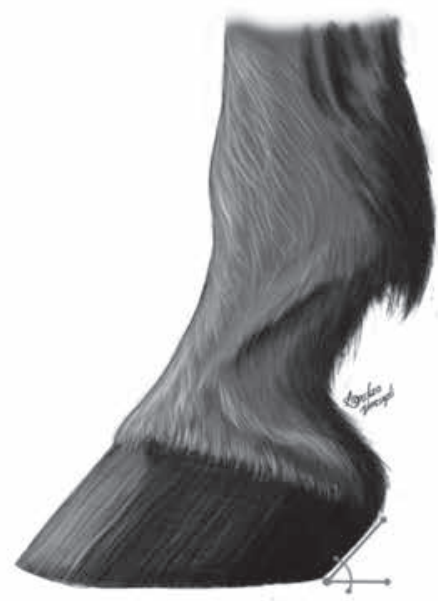

C

Fig. 1 Reference points for assessing the heels balance. Heel length (A), heel height ( $\left.b^{\prime \prime}\right)$ and heel angle (C). In $b^{\prime}$ the hoof height is demonstrated, that together with the measurement $b^{\prime \prime}$ were the measurements indirectly by trigonometric equations. Courtesy: L. C. Vincensi. Bezugspunkte für die Beurteilung der Fersenbalance. Fersenlänge (A), Fersenhöhe (b") und Fersenwinkel (C). In b' wird die Hufhöhe gezeigt, dass zusammen mit der Messung b" die Messungen indirekt durch trigonometrische Gleichungen waren. Höflichkeit: L. C. Vincensi 


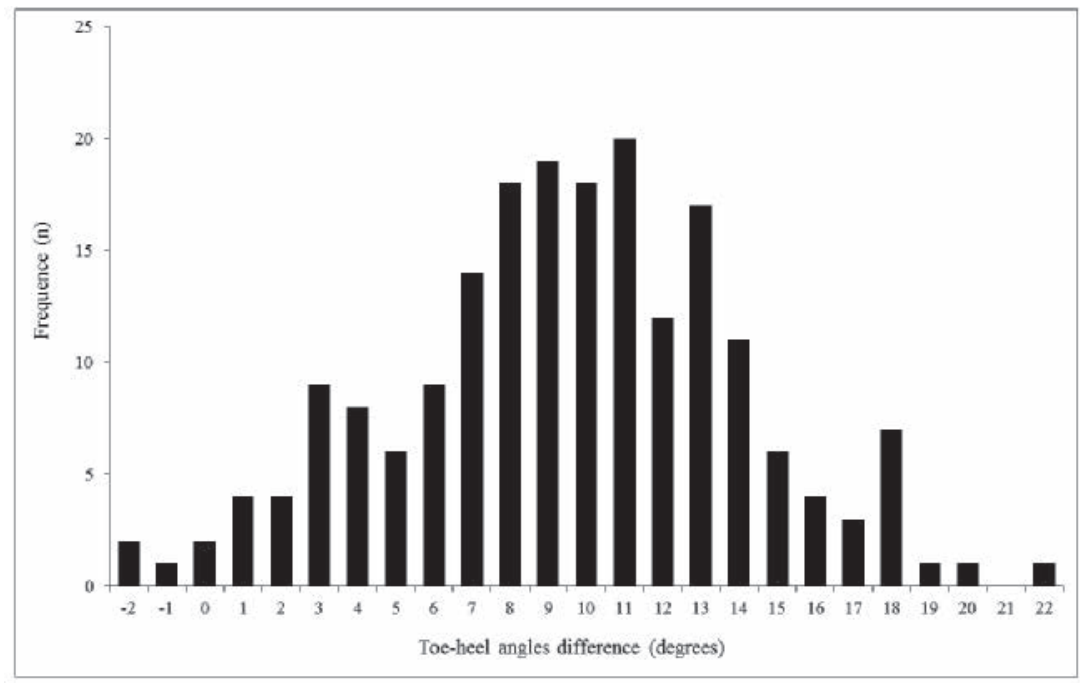

Fig. 2 Distribution of the frequencies of toeheel angles differences (degrees) in 197 hooves of 50 horses of the Campeiro breed. | Verteilung der Häufigkeit von Zehen-Fersen-Winkeldifferenzen (Grad) in 197 Hufen von 50 Pferden der Campeiro-Pferden.

Table 1 Mean and standard deviation $(x \pm S D)$ of the measures of the fore and hindlimbs of 50 horses, male $(n=8)$ and female $(n=42)$ of the Campeiro breed. I Mittelwert und Standardabweichung $(x \pm S D)$ der Maße der Vorder- und Hinterbeine von 50 Pferden, männlich $(n=8)$ und weiblich ( $n=42)$ der Campeiro-Pferde.

\begin{tabular}{|c|c|c|c|c|c|c|}
\hline \multirow{2}{*}{ Variables } & \multicolumn{4}{|c|}{ Limb } & \multirow[b]{2}{*}{ Forelimb* } & \multirow[b]{2}{*}{ Hindlimb* } \\
\hline & LF & RF & $\mathrm{LH}$ & $\mathrm{RH}$ & & \\
\hline Frog length $(\mathrm{cm})$ & $8.0 \pm 0.5$ & $8.2 \pm 0.5$ & $7.9 \pm 0.5$ & $7.9 \pm 0.7$ & $8.1 \pm 0.5 a$ & $7.9 \pm 0.6 b$ \\
\hline Frog width $(\mathrm{cm})$ & $5.3 \pm 0.8$ & $5.2 \pm 0.8$ & $5.8 \pm 0.7$ & $5.8 \pm 0.7$ & $5.2 \pm 0.8$ & $5.8 \pm 0.7$ \\
\hline Length of lateral heel $(\mathrm{cm})$ & $5.1 \pm 0.5$ & $5.0 \pm 0.5$ & $4.3 \pm 0.6$ & $4.3 \pm 0.6$ & $5.1 \pm 0.5$ & $4.3 \pm 0.6$ \\
\hline Length of medial heel $(\mathrm{cm})$ & $5.1 \pm 0.6$ & $5.0 \pm 0.5$ & $4.2 \pm 0.5$ & $4.2 \pm 0.5$ & $5.0 \pm 0.6$ & $4.2 \pm 0.5$ \\
\hline Height of lateral heel (cm) & $3.5 \pm 0.6$ & $3.3 \pm 0.5$ & $2.8 \pm 0.5$ & $2.6 \pm 0.4$ & $3.4 \pm 0.5$ & $2.7 \pm 0.5$ \\
\hline Height of medial heel $(\mathrm{cm})$ & $3.5 \pm 0.5$ & $3.3 \pm 0.5$ & $2.9 \pm 0.5$ & $2.8 \pm 0.5$ & $3.4 \pm 0.5$ & $2.9 \pm 0.5$ \\
\hline Toe length $(\mathrm{cm})$ & $8.6 \pm 0.6$ & $8.6 \pm 0.6$ & $8.5 \pm 0.6$ & $8.6 \pm 0.7$ & $8.6 \pm 0.6$ & $8.6 \pm 0.7$ \\
\hline Hoof height $(\mathrm{cm})$ & $6.6 \pm 0.4$ & $6.6 \pm 0.5$ & $6.5 \pm 1.0$ & $6.5 \pm 0.5$ & $6.7 \pm 0.5$ & $6.6 \pm 0.8$ \\
\hline Toe angle $\left({ }^{\circ}\right) \dagger$ & $50.9 \pm 2.9$ & $50.5 \pm 3.7$ & $51.8 \pm 3.2$ & $51.5 \pm 3.0$ & $50.7 \pm 3.3 a$ & $51.7 \pm 3.1 b$ \\
\hline Angle of lateral heel $\left({ }^{\circ}\right) \dagger$ & $43.3 \pm 4.4$ & $41.8 \pm 5.2$ & $42.2 \pm 4.5$ & $38.6 \pm 4.0$ & $42.5 \pm 4.8 a$ & $40.4 \pm 4.6 b$ \\
\hline Angle of medial heel $\left({ }^{\circ}\right) \dagger$ & $43.4 \pm 4.8$ & $41.5 \pm 4.9$ & $42.9 \pm 4.3$ & $41.2 \pm 4.6$ & $42.5 \pm 4.9$ & $42.0 \pm 4.5$ \\
\hline Hoof width (cm) & $12.0 \pm 0.7$ & $12.0 \pm 0.7$ & $11.2 \pm 0.5$ & $11.1 \pm 0.5$ & $12.0 \pm 0.7 a$ & $11.1 \pm 0.5 b$ \\
\hline Hoof length $(\mathrm{cm})$ & $13.0 \pm 0.7$ & $13.2 \pm 0.8$ & $12.5 \pm 0.6$ & $12.6 \pm 0.6$ & $13.1 \pm 0.7 a$ & $12.5 \pm 0.6 b$ \\
\hline Coronet circumference (cm) & $33.4 \pm 1.3$ & $33.4 \pm 1.3$ & $32.9 \pm 1.2$ & $32.8 \pm 1.2$ & $33.4 \pm 1.3$ & $32.8 \pm 1.2$ \\
\hline Body mass and hoof area ratio $\left(\mathrm{kg} / \mathrm{cm}^{2}\right)^{*}$ & $4.6 \pm 0.4$ & $4.6 \pm 0.4$ & $4.8 \pm 0.4$ & $4.8 \pm 0.4$ & - & - \\
\hline
\end{tabular}

LF: Left forelimb; RF: Right forelimb; LH: Left hindlimb and RH: Right hindlimb./*Averages followed by different lowercase letters on the line differ from one another $(\mathrm{P}<0.05)$. / †According Mann-Whinney test.

Table 2 Frequency of changes in the hoof balance of 50 horses, male $(n=8)$ and females $(n=42)$ of the Campeiro breed. | Häufigkeit von Veränderungen im Huf Symmetrie von 50 Pferden, männlich $(n=8)$ und weiblich $(n=42)$ der Campeiro-Pferden.

\begin{tabular}{|c|c|c|c|c|c|}
\hline \multirow{2}{*}{ Imbalance } & \multicolumn{4}{|c|}{ Limb } & \multirow{2}{*}{ Total } \\
\hline & LF & RF & $\mathrm{LH}$ & $\mathrm{RH}$ & \\
\hline Frog contracted & $52.0 \%(26 / 50)$ & $66.0 \%(33 / 50)$ & $16.0 \%(8 / 50)$ & $27.1 \%(13 / 48)$ & $40.4 \%(80 / 198)$ \\
\hline Heel vertical imbalance & $8.0 \%(4 / 50)$ & $14.0 \%(7 / 50)$ & $14.0 \%(7 / 50)$ & $16.7 \%(8 / 48)$ & $13.1 \%(26 / 198)$ \\
\hline Heel linear imbalance & $10.0 \%(5 / 50)$ & $12.0 \%(6 / 50)$ & $22.0 \%(11 / 50)$ & $10.4 \%(5 / 48)$ & $13.6 \%(27 / 198)$ \\
\hline Heel angular imbalance & $22.0 \%(11 / 50)$ & $28.0 \%(14 / 50)$ & $32.0 \%(16 / 50)$ & $39.6 \%(19 / 48)$ & $30.3 \%(60 / 198)$ \\
\hline Underrun heels & $70.0 \%(35 / 50)$ & $84.0 \%(42 / 50)$ & $81.6 \%(40 / 49)$ & $95.8 \%(46 / 48)$ & $82.7 \%(163 / 197)$ \\
\hline Hooves smalls* & - & - & - & - & $0.00 \%(0 / 50)$ \\
\hline
\end{tabular}

LF: Left forelimb; RF: Right forelimb; LH: Left hindlimb and RH: Right hindlimb. / *Measured in left forelimb. 
Occasionally, some professionals recommend changes in trimming patterns to improve gait quality. Notwithstanding, the gaited is a genetic inheritance, spontaneously manifested by equines (Patterson et al. 2015, Andersson et al. 2012),

Table 3 Frequencies of associated heels imbalances of 50 horses, male $(n=8)$ and females $(n=42)$ of the Campeiro breed. Häufigkeiten der damit verbundenen Fersen Ungleichgewichte von 50 Pferden, männlich $(n=8)$ und weiblich $(n=42)$ der Campeiro-Pferden.

\begin{tabular}{ccccc}
\hline Limb & \multicolumn{4}{c}{ Heels imbalances } \\
\hline & $\mathrm{V} \times \mathrm{L}$ & $\mathrm{V} \times \mathrm{A}$ & $\mathrm{L} \times \mathrm{A}$ & $\mathrm{V} \times \mathrm{L} \times \mathrm{A}$ \\
\hline \multirow{2}{*}{$\mathrm{LF}$} & $2.0 \%$ & $4.0 \%$ & $2.0 \%$ & $0.0 \%$ \\
& $(1 / 50)$ & $(2 / 50)$ & $(1 / 50)$ & $(0 / 50)$ \\
$\mathrm{H}$ RF & $4.0 \%$ & $10.0 \%$ & $0.0 \%$ & $0.0 \%$ \\
& $(2 / 50)$ & $(5 / 50)$ & $(0 / 50)$ & $(0 / 50)$ \\
$\mathrm{LH}$ & $4.0 \%$ & $2.0 \%$ & $2.0 \%$ & $4.0 \%$ \\
& $(2 / 50)$ & $(1 / 50)$ & $(1 / 50)$ & $(2 / 50)$ \\
$\mathrm{RH}$ & $4.2 \%$ & $8.4 \%$ & $0.0 \%$ & $6.25 \%$ \\
& $(2 / 48)$ & $(4 / 48)$ & $(0 / 48)$ & $(3 / 48)$ \\
Total & $3.5 \%$ & $6.1 \%$ & $1.0 \%$ & $2.5 \%$ \\
& $(7 / 198)$ & $(12 / 198)$ & $(2 / 198)$ & $(5 / 198)$ \\
\hline
\end{tabular}

LF: Left forelimb; RF: Right forelimb; LH: Left hindlimb and RH: Right hindlimb. $V$ : heel vertical imbalance; $L$ : heel linear imbalance; $A$ : heel angular imbalance. and gait pattern can be influenced by changes in trimming and shoeing, as demonstrated by Weishaupt et al. (2014, 2013) and Waldern et al. (2014) on Icelandic horses.

The Campeiro horses' hoof area, calculated by Turner's formula (2003), was below the critical values, showing that animal body mass appears to be adequate for hoof size, which may be a positive feature in traveling animals long distances, like walking horses. However, the hooves imbalances identified in our study may limit the use of these animals for such activity due to the increased risk of injury. There were no differences in coronet circumference measures between left and right hooves. Thus, measures from either limb could be applied to the formula used to calculate area: body mass ratio. This leads to the reflection that all hooves have similar sizes; however, the load imposed on the forelimbs is greater than that on the hindlimbs (Beeman 2008).

Whether in fore and hind feet, the mean toe angles may be smaller than they really are. This is due to the high frequency of underrun heels, since low heel angles are associated with longer toe lengths and hence smaller toe angles (Hunt 2012). This is contributed by the low correlation between body mass and toe length since these variables present a good correlation (Balch et al. 1991). However, this is speculative since

Table 4 Mean and standard deviation $(x \pm S D)$ of the levels of copper, iron, sodium, potassium, zinc, calcium and magnesium, expressed in ppm (dry matter) on the wall, sole and frog of 30 Campeiro horses. I Mittelwert und Standardabweichung ( $x \pm$ SD) der Gehalte an Kupfer, Eisen, Natrium, Kalium, Zink, Kalzium und Magnesium, ausgedrückt in ppm an Wand, Sohle und Strahl von 30 Campeiro-Pferden.

\begin{tabular}{|c|c|c|c|}
\hline \multirow[t]{2}{*}{ Mineral (ppm) } & \multicolumn{3}{|c|}{ Hoof region } \\
\hline & Wall & Sole & Frog \\
\hline Copper & $3.51 \pm 1.6^{a}$ & $2.47 \pm 0.96^{\mathrm{ab}}$ & $2.07 \pm 0.81^{\mathrm{b}}$ \\
\hline Iron & $290.58 \pm 256.26^{a}$ & $52.90 \pm 54.25^{b}$ & $130.09 \pm 128.64^{b}$ \\
\hline Sodium & $410.33 \pm 142.60$ & $437.33 \pm 109.10$ & $481.07 \pm 168.40$ \\
\hline Potassium & $460.74 \pm 425.02^{b}$ & $404.07 \pm 445.22^{b}$ & $834.40 \pm 709.33^{a}$ \\
\hline Zinc & $163.88 \pm 36.70^{\circ}$ & $88.00 \pm 23.49^{b}$ & $35.56 \pm 8.80^{c}$ \\
\hline Calcium & $178.79 \pm 137.16^{b}$ & $103.86 \pm 72.85^{b}$ & $366.88 \pm 180.51^{a}$ \\
\hline Magnesium & $960.24 \pm 631.77^{a b}$ & $738.22 \pm 566.65^{b}$ & $1389.45 \pm 768.73^{a}$ \\
\hline
\end{tabular}

In the rows, values followed by different lowercase letters differ from each other $(P<0.05)$.

Table 5 Mean and standard deviation $(x \pm S D)$ of the levels of copper, iron, sodium, potassium, zinc, calcium and magnesium, expressed in ppm (dry matter) on the wall, sole and frog of the dark and light hooves of Campeiro horses. I Mittelwert und Standardabweichung ( $x \pm$ SD) der Gehalte an Kupfer, Eisen, Natrium, Kalium, Zink, Kalzium und Magnesium, ausgedrückt in ppm an Wand, Sohle und Strahl der dunklen und hellen Hufe von Campeiro-Pferden.

\begin{tabular}{l|ccc|ccc}
\hline $\begin{array}{l}\text { Mineral } \\
(\mathrm{ppm})\end{array}$ & \multicolumn{3}{|c|}{ Hoof Dark } & \multicolumn{3}{c}{ Hoof Light } \\
\hline & Wall $(\mathrm{n}=17)$ & Sole $(\mathrm{n}=10)$ & Frog $(\mathrm{n}=11)$ & Wall $(\mathrm{n}=13)$ & Sole $(\mathrm{n}=20)$ & Frog $(\mathrm{n}=19)$ \\
\hline Copper & $4.03 \pm 1.21^{\mathrm{a}}$ & $2.60 \pm 0.91^{\mathrm{b}}$ & $1.97 \pm 0.63^{\mathrm{b}}$ & $2.61 \pm 1.89$ & $2.37 \pm 1.03$ & $2.17 \pm 1.01$ \\
\hline Iron & $411.45 \pm 247.11^{\mathrm{Aa}}$ & $79.18 \pm 73.94^{\mathrm{Ab}}$ & $172.04 \pm 169.96^{\mathrm{b}}$ & $129.43 \pm 95.66^{\mathrm{Ba}}$ & $39.77 \pm 36.86 \mathrm{~B}^{\mathrm{b}}$ & $109.11 \pm 101.57^{\mathrm{a}}$ \\
\hline Sodium & $428.24 \pm 144.75$ & $474.00 \pm 98.45$ & $449.00 \pm 142.24$ & $386.92 \pm 141.97$ & $419.00 \pm 111.87$ & $498.89 \pm 182.72$ \\
\hline Potassium & $460.00 \pm 423.84$ & $588.89 \pm 657.77^{\mathrm{A}}$ & $1030.00 \pm 970.67^{\mathrm{A}}$ & $461.82 \pm 447.46^{\mathrm{ab}}$ & $311.67 \pm 269.14^{\mathrm{Bb}}$ & $724.38 \pm 516.38^{\mathrm{Ba}}$ \\
\hline Zinc & $171.42 \pm 36.00^{\mathrm{a}}$ & $102.49 \pm 27.50^{\mathrm{b}}$ & $34.34 \pm 10.70 \mathrm{c}$ & $154.02 \pm 36.63^{\mathrm{a}}$ & $80.76 \pm 17.84^{\mathrm{b}}$ & $36.24 \pm 7.81 \mathrm{c}$ \\
\hline Calcium & $181.55 \pm 124.43^{\mathrm{b}}$ & $121.09 \pm 89.41^{\mathrm{b}}$ & $350.25 \pm 159.61^{\mathrm{a}}$ & $174.53 \pm 161.22^{\mathrm{b}}$ & $93.52 \pm 62.00^{\mathrm{b}}$ & $377.64 \pm 196.85^{\mathrm{a}}$ \\
\hline Magnesium & $1059.16 \pm 594.16^{\mathrm{ab}}$ & $749.86 \pm 383.44^{\mathrm{b}}$ & $1607.91 \pm 746.66^{\mathrm{a}}$ & $816.36 \pm 685.41$ & $731.76 \pm 657.27$ & $1149.14 \pm 755.83$ \\
\hline
\end{tabular}

In the rows, values followed by different capital letters for the same region in the different distinct and distinct groups for the different regions in the same group differ $(P<0.05)$. 
current concepts of hoof balance indicate that hoof angles is an individual aspect and is related to a proper hoof-pastern alignment (O'Grady and Poupard 2003, Balch et al. 1995).

The frequency of hoof imbalances in Campeiro horses is a worrying factor because it reflects the lack of hoof care and/ or lack of an environment that promotes a natural fit of wear. Nearly $50 \%$ of the evaluated animals had frog contraction (80/198), about $57 \%$ (113/198) presented heel imbalances, and more than $80 \%(163 / 197)$ had underrun heels. These statistics are supported by other studies of both feral and domesticated horses (Caldwell et al. 2016, Hampson et al. 2010).

The palmar/plantar portion of hooves has a critical role during movement and therefore is commonly involved in lameness. Despite advances in knowledge of equine disorders over the last 50 years, there is still controversy on the diagnosis and treatment of abnormalities in this region (Hunt 2012), and underrun heels are the most common abnormalities. Our results on underrun heels were similar to those of other studies (Balch et al. 2001, Kane et al. 1998, Wright 1993). In this respect, a detailed biometric analysis of the heels may help to understand heel balance and define imbalances.

When individually assessed (Table 2), heel imbalances were more frequent compared to between their combinations (Table 3). This suggests an adaptation of the heels to maintain a medial-lateral balance. Therefore, the balance in the palmar/plantar region should be interpreted through the functional conformation of this area and not simply in an isolated measure. Using more than one measure to evalvate the balance in hoof palmar/plantar region proved to be most appropriate for the analysis of medial-lateral balance as regards the identification of imbalances, besides improving further strategies on hoof balancing. However, more research is still required to determine the maximum differences between the medial and lateral portions. This inference extends to the other proportions and equations commonly used in equine podometry. As far as in the available literature, no description of the process for obtaining them has been published.

It is noteworthy that the measurement method proposed in this study brought more confidence to the results, especially for the height of heels. Direct evaluation of height of heels is hampered by position instability, where uneven weight distribution determines or generates distance oscillations, and requires a surface flat enough to perform measurements. By the use of trigonometry, these variations to measure the height of heel are no longer important because measuring the length and angle of heels, used to calculate height of heels, depends only on the accuracy of the equipment and operator.

Most of the hooves (77.16\%, 152/197) showed angular differences between toe and heel (palmar/plantar region) equal to or greater than seven degrees, and in some cases with values above 20 degrees (Figure 2). Such frequency has been commonly observed in several other equine populations, which has been even deemed as normal (O'Grady 2011 ). No cut-off point for misalignment was found in the literature; however, the equality between toe and heel angles appears does not seem to be the most correct. As in many aspects of biology, determining a range of variation is the most appropriate to do, and should be the focus in future studies. The terms long toe/low heel and underrun heels are frequent in the literature and describe different degrees of toe/heel alignment. O'Grady (2011) frankly discussed the differences of both, thus being a suggestion for consultation to readers.

In any case, predispositions to chronic injuries due to a direct influence of hoof conformation on locomotion biomechanics must be alerted. Likewise, Balch et al. (2001) carried out postmortem examinations of 90 racehorses and identified underrun heels in $97 \%$ of them, being then considered as a risk factor for catastrophic injuries in this group of animals. These results are worrying and reinforce the need for further discussion on the integrity of the palmar/plantar region of hooves associated with the issue that lower-base heel treatment is difficult. Often, heel conformation can only be maintained rather than improved (O'Grady 2011). Measures to prevent this condition should be prioritized, teaching good hoof management practices.

Our findings indicate that hoof care is still below ideal conditions, which is also seen in other equine populations, even those with more attention, as presented in other studies. Canto et al. (2006) assessed Crioulo horses in training and identified that almost half of the studied animals (49.48\%) showed a medial/lateral imbalance. When evaluating horses of the same breed, Dau et al. (2015) identified long toes in $89.7 \%$ of the animals, long distance from the breaking point in $67.2 \%$, underrun heels in $48.3 \%$, shallow soles in $33.3 \%$, asymmetry between contralateral hoof angle in $27.6 \%$, and medial-lateral imbalance in $15.5 \%$. More worrying still, however, is the situation in less assisted populations, as identified by Schade et al. (2013). These authors assessed hoof balance in cart horses and identified the following alterations: asymmetry between the hooves of contralateral limbs; acute toe angle; frog contraction in the forelimbs (100\%), right hindlimb (70.5\%) and left hindlimb (66.0\%); and medial/lateral imbalance in the forelimbs (4.6 to $6.8 \%)$ and in the hindlimbs (4.6 to $13.6 \%)$.

Despite the high frequency of hooves imbalances of Campeiro horses, we can notice that the horn tissue is of good quality and has adapted to critical conditions. This can be attributed to the absence of horseshoes, the possibility of moving over a wide area, the predominantly feeding of pastures, that is, an environment closer to that which the horses developed. This helps us to see that confinement must be minimized in some way to provide healthy hooves.

\section{Mineral contents}

In all conditions evaluated, the highest $Z n$ contents were always found on the hoof wall, such as those found by Tocci et al. (2015) for Anglo-Arabian and Monterufolie ponies. As the wall is responsible for impact reception and weight support, it is expected that this tissue present characteristics that are consistent with such functions. Thus, the highest levels of $\mathrm{Zn}$ are important since this element acts in the catalytic, structural, 
and regulatory steps of keratinization (Smart and Cymbaluk 1997, Cousins 1996). Catalytic steps involve enzymes acting on keratinocyte nucleic acids, while structural ones are responsible for protein formation (Cousins 1996). In regulatory steps, Zn acts on calmodulin, which is responsible for interactions between $\mathrm{Zn}$ and $\mathrm{Ca}$ (Tomlinson et al. 2004).

Although the association of hardness with pigmentation of hooves still divides opinions, $\mathrm{Cu}$ is associated with both keratin structuring (hardness) and in melanin synthesis (pigmentation) (Pardo and Reis 2008). However, nothing was confirmed in this study since the Cu contents were similar between dark and light hooves, corroborating the findings of Faria et al. (2005) and Landeau et al. (1983). In contrast, Leach (1980) presents a very interesting observation in this respect, this author points to an indirect evidence that the resistance of pigmented and non-pigmented hooves is similar in animals with striped hooves. If the wall parts in different colors were substantially different in resistance, a shearing force between them would be exerted when the wall was subjected to an impact, forming cracks and/ or separation of the parts, which does not occur in practice.

Alterations in concentrations of the mineral elements studied here are only hypotheses in view of a non-correlation of keratinized tissue with physical/mechanical variables, revealing a limitation of the present study. However, there are similarities with mineral contents identified in other studies (Tocci et al. 2015, Sargentini et al. 2012, Faria et al. 2005), demonstrates the similarity of these in the horn tissues of equine hoof, which offers consistent evidence in the deposition and function of these elements.

The current thinking on the relationship between animal nutrition and hoof integrity places a strong emphasis on the role of $\mathrm{Zn}$ in the metabolism in hoof tissue to the detriment of the other minerals. A healthy hoof reflects on a healthy equine; thus, mineral deficiencies in diets will also affect hooves. Broadly speaking, the maximum growth, attainment, and maintenance of the integrity of hooves come from a balanced diet that meets the animal requirements related to all nutrients. Still, no evidence has been proven that a surplus supply of one or more nutrients responds better than that in recommended amounts (Ott and Johnson 2001, Butler and Hintz 1977).

\section{Conclusion}

The hoof conformation of Campeiro horses is similar to those described in the specialized literature for other breeds, both in terms of size and proportions. However, the high frequency of hoof imbalances found may serve as an alert for owners to reconsider certain management practices.

The hoof and heel heights can be measured by equations, which may be part of future methods of study and professional routine.

The palmar/plantar region of hooves appears to have a compensation mechanism to maintain hoof balance in cases of asymmetry. Investigations that are more objective are still needed to identify and/or validate the methods of hoof asymmetry evaluation that are encountered in the literature.
Although there are differences in content for some minerals between hooves of different colorations, this fact has no influence on the quality of both of them (dark and light hooves). No association between strength and coloration was found for hoof horny tissues.

\section{Manufacturers' addresses}

1 Ruidoso, Sam and Hazel Sayers, Hobbs, New Mexico, USA. 2 Multiwave 300, PerkinElmer, Billerica, Massachusetts, USA

${ }^{3}$ AAnalyst 200, PerkinElmer, Billerica, Massachusetts, USA.

${ }^{4}$ DM-62, Digimed, Campo Grande, Mato Grosso do Sul, Brazil.

\section{References}

Andersson L. S., Larhammar M., Memic F., Wootz H., Schwochow D., Rubin C. J., Imsland F. (2012) Mutations in DMRT3 affect locomotion in horses and spinal circuit function in mice. Nature 488, 642-646; DOI 10.1038/nature 11399

Back W., Remmen J. L. M. A., Knaap J., Koning J. D. (2003) Effect of lateral heel wedges on sagittal and transverse plane kinematics of trotting Shetland ponies and the influence of feeding and training regimes. Equine Vet. J. 35, 606-612; DOI 10.2746/042516403775467252

Balch O., Butler D., White K., Metcalf S. (1995) Hoof balance and lameness: improper toe length, hoof angle, and mediolateral balance. Compend. Contin. Educ. Vet. 17, 1275-1283

Balch O., White K., Butler D. (1991) Factors involved in the balancing of equine hooves. J. Am. Vet. Med. Assoc. 198, 1980-1989; PMID 1874681

Balch O. K., Helman R. G., Collier M. A. (2001) Underrun heels and toe-grab length as possible risk factors for catastrophic musculoskeletal injuries in Oklahoma racehorses. Proc. Am. Ass. Equine Practnrs. 47, 334-338

Beeman, G. M. (2008) Conformation of the horse: Relationship of form to function. Proc. Am. Ass. Equine Practnrs. 54, 63-68.

Bragulla H. H., Reese S., Budras K. D., Steinberg W. (1999) How structures in bovine hoof epidermis are influenced by nutritional factors. Anat. Histol. Embryol. 28, 103-108; DOI 10.1046/i.14390264.1999.00180.x

Butler K. D., Hintz H. F. (1977) Effect of level of feed intake and gelatin supplementation on growth and quality of hoofs of ponies. J. Anim. Sci. 44, 257-261; DOI 10.2527/jas1977.442257x

Caldwell M. N., Allan L. A., Pinchbeck G. L., Clegg P. D., Kissick K. E., Milner P. I. (2016) A test of the universal applicability of a commonly used principle of hoof balance. Vet. J. 207, 169-176; DOI 10.1016/i.tvil.2015.10.003

Canto L. S., De La Corte F. D., Brass K. E., Ribeiro M. D. (2006) Frequência de problemas de equilíbrio nos cascos de cavalos crioulos em treinamento. Braz. J. Vet. Res. Anim. Sci. 43, 489-495; DOI 10.11606/issn. 1678-4456.bjvras.2006.26464

Cousins R. J. (1996) Zinc. In: Present Knowledge in Nutrition, 7th edn., Ed: E. E. Ziegler, L. J. Filer, Jr., International Life Sciences Institute Press, Washington, US, 293-306

Crevier-Denoix N., Roosen C., Dardillat C., Pourcelot P., Jerbi H., Sanaa M., Denoix J. M. (2001) Effects of heel and toe elevation upon the digital joint angles in the standing horse. Equine Vet. J. 33, 74-78; DOI 10.1111/i.2042-3306.2001.tb05364.x

Dau S. L., Noro M., Pretto N., Alves L. G., Alves L. P. (2015) Equilíbrio podal de cavalos crioulos de laço no Norte do Rio Grande do Sul. Rev. Bras. Med. Vet. 37, 366-370

Falcão R. F. (2002) Variação genética, fenotípica e caracterização do cavalo Campeiro Master's Dissertation. Universidade de Brasília, Brasília, $72 \mathrm{p}$ 
Faria G. A., Rezende A. S. C., Sampaio I. B. M., Lana A. M. Q., Moura R. S., Madureira J. S., Resende M. C. (2005) Composição química dos cascos de equinos das raças Pantaneira e Mangalarga Marchador. Arq. Bras. Med. Vet. Zootec. 57, 697-701; DOI 10.1590/S0102-09352005000500016

Fonteque J. H., Ceccatto M. L., Bagio R. M., Schade J., Saito M. E., Martins V. V., Fonteque G. V., Martins E., Ramos A. F., Albuquerque M. S. M., Costa D. (2016) Hematological profile, total plasma protein and fibrinogen concentrations of clinically healthy adult Campeiro horses. Cienc. Rural. 46, 144-149; DOI 10.1590/0103-8478cr20141408

Hampson B. A., Ramsey G., Macintosh A. M. H., Mills P. C., De Laat M. A., Pollitt C. C. (2010) Morphometry and abnormalities of the feet of Kaimanawa feral horses in New Zealand. Aust. Vet. J. 88, 124-131; DOI 10.1111/i.1751-0813.2010.00554.x

Hinterhofer C., Stanek C., Haider H. (2000) The effect of flat horseshoes, raised heels and lowered heels on the biomechanics of the equine hoof assessed by finite element analysis (FEA). J. Vet. Med. Series A. 47, 73-82; DOI 10.1046/j.1439-0442.2000.00263.x

Hunt R. J. (2012) Farriery for the hoof with low or underrun heels. Vet. Clin. N. Am.: Equine Pract. 28, 351-364; DOI 10.1016/i. creq.2012.06.002

Johnson A. B., Schugel L. M. (1994) The role of trace elements in bovine lameness. In: 8th International Symposium on Disorders of the Ruminant Digit and Conference on Bovine Lameness, University of Saskatchawen, Banff, Canadá, 355-362

Kane A. J., Stover S. M., Bock K. B., Gardner I. A. (1998) Hoof balance characteristics associated with catastrophic injury of Thoroughbred racehorses. Proc. Am. Ass. Equine Practnrs. 44, 281-283.

Landeau L. J., Barrett D. J., Batterman S. C. (1983) Mechanical properties of equine hooves. Am. J. Vet. Res. 44, 100-102; PMID 6824212.

Lazzeri L. (1992) Lições de podologia equina. EV-UFMG, Belo Horizonte, BR, 224p

Leach D. H. (1980) The structure and function of the equine hoof wall. PhD Thesis, University of Saskatchawen, Saskatoon, Saskatchewan, 1980

Mariante A. S., Cavalcante N. (2000) Animais do descobrimento. Raças domésticas da história do Brasil. Embrapa, Brasília, BR, $232 \mathrm{p}$

Melo U. P. D., Ferreira C., Santiago R. M. F. W., Palhares M. S., Maranhão R. D. P. A. (2006) Equilíbrio do casco eqüino - Uma revisão. Ciênc. Anim. Bras. 7, 389-398.

Nicoletti J. L. M., Schlegel C., Thomassian A., Hussni C. A., Alves A. L. G. (2000) Mensuração do casco de equinos para identificação objetiva de anormalidades de conformação. Vet. Not. 6, 61-68

O'Grady S. E. (2011) Foot care and farriery. In: Adams and Stashak's Lameness in Horses, 6th edn., Ed: G. M. Baxter, Wiley-Blackwell, Washington, US, 1179-1217

O'Grady S. E., Poupard D. A. (2003) Proper physiology and horseshoeing. Vet. Clin. N. Am.: Equine Pract. 19, 333-351; DOI 10.1016/S0749-0739 (03)00020-8

Ott E. A., Johnson E. L. (2001) Effect of trace mineral proteinates on growth and skeletal and hoof development in yearling horses. J. Equine Vet. Sci. 21, 287-291; DOI 10.1016/S0737-0806 (01)70059-7

Ovnicek G. D., Page B. T., Trotter G. W. (2003) Natural balance trimming and shoeing: Its theory and application. Vet. Clin. N. Am.: Equine Pract. 19, 353-377; DOI 10.1016/s0749-0739 (03)00017-8

Pardo P. E., Reis L. S. (2008) Nutrientes e nutracêuticos em grandes animais. In: Manual de Terapêutica Veterinária, $3^{\text {rd }}$ edn., Ed: S. F. Andrade, Roca, São Paulo, BR, 808-823

Patterson L., Staiger E. A., Brooks S. A. (2015) DMRT3 is associated with gait type in Mangalarga Marchador horses, but does not control gait ability. Anim. Genet. 46, 213-215; DOI 10.1111/ age. 12273

Sargentini C., Tocci R., Andrenelli L., Giorgetti A. (2012) Preliminary studies on hoof characteristics in Amiata donkey. Ital. J. Anim. Sci. 11, 123-127; DOI 10.4081/ijas.2012.e22
Schade J., Baldissera R., Paolini E., Fonteque J. H. (2013) Biometria do equilíbrio podal em equinos de tração pertencentes ao Programa de Extensão" Amigo do Carroceiro" do Centro de Ciências Agroveterinárias da Universidade do Estado de Santa Catarina no município de Lages/SC, Brasil. Cien. Rural, 43, 456-461; DOI 10.1590/S0103-84782013000300013

Smart M., Cymbaluk N. F. (1997) Role of nutritional supplements in bovine lameness. In: Lameness in Cattle, $3^{\text {rd }}$ edn., Ed: P. R. Greenough and A. D. Weaver, Saunders, Philadelphia, USA, 145-161

Solano G. A., Silva M. C., Rocha F. E. C., Silva D. C., Lopes F. B., Fioravanti M. C. S., Sereno J. R. B. (2013) Análise do discurso de criadores de cavalo Campeiro no Sul do Brasil: instrumento de diagnóstico para conservação e fortalecimento da raça. Act. Iberoam. Conser. Anim. 3, 8-14

Souza A. F., Fonteque J. H., Costa D. (2018) Cavalo Campeiro: Passado, Presente e Futuro do Marchador das Araucárias. Rev. Acad. Ciênc. Anim. 16, 1-12; DOI 10.7213/1981-4178.2018.162102

Souza A. F., Kunz J. R., Laus R., Moreira M. A., Muller T. R., Fonteque J. H. (2016a) Biometrics of hoof balance in equids. Arq. Bras. Med. Vet. Zootec. 68, 825-831; DOI 10.1590/1678-4162-8848

Souza A. F., Schade J., Kunz J. R., Ramos A. F., Albuquerque M. S. M., Fonteque G. V., Costa D., Saito M. E., Fonteque J. H. (2016b) Serum biochemical profile from clinically healthy Campeiro horses. Arq. Bras. Med. Vet. Zootec. 68, 839-844; DOI 10.1590/16784162-8782

Souza A. F., Schade J., Ramos A. F., Albuquerque M. S. M., Fonteque G. V., Costa D., Muller T. R., Fonteque J. H. (2019). Serum proteinogram of the Campeiro horse. Arq. Bras. Med. Vet. Zootec. 71, 363-368; 10.1590/1678-4162-10102

Stachurska A., Kolstrung R. Y. S. Z. A. R. D., Pieta M., Silmanowicz P. I. O. T. R., Klimorowska A. N. N. A. (2008) Differentiation between fore and hind hoof dimensions in the horse (Equus caballus). Arch. Anim. Breed., 51, 531-540; DOI 10.5194/aab-51-531-2008

Tedesco M. J., Gianello C., Bissani C. A., Bohnen H., Volkweiss S. J. (1995) Análises de solo, plantas e outros materiais, 2nd edn., Editora UFRGS, Porto Alegre, BR. 174p

Tocci R., Sargentini C., Martini A., Giorgetti A. (2015) Qualitative hoof characteristics in Anglo-arabian horses and Monterufoli Ponies reared in the same farm. Global J. Anim. Sci. Res. 3, 20-29

Tomlinson D. J., Mülling C. H., Fakler T. M. (2004) Invited review: formation of keratins in the bovine claw: roles of hormones, minerals, and vitamins in functional claw integrity. J. Dairy. Sci. 87, 797-809; DOI 10.3168/jds.S0022-0302 (04)73223-3

Turner T. A. (1986) Navicular disease management: Shoeing principles. Proc. Am. Ass. Equine Practnrs. 32, 625-633

Turner T. A. (1992) The use of hoof measurements for the objective assessment of hoof balance. Proc. Am. Ass. Equine Practnrs. 38, 389-395

Turner T. A. (2003) Examination of the equine foot. Vet. Clin. N. Am.: Equine Pract. 19, 309-332; DOl 10.1016/S0749-0739 (03)00023-3

Waldern N. M., Wiestner T., Ramseier L. C., Amport C., Weishaupt M. A. (2013). Effects of shoeing on limb movement and ground reaction forces in Icelandic horses at walk, tölt and trot. Vet. J., 198, 103-108; DOI 10.1016/i.tvil.2013.09.042

Weishaupt M., Waldern N., Kubli V., Wiestner T. (2014) Effects of shoeing on breakover forces in Icelandic horses at walk, tölt and trot. Equine Vet. J. 46, 51-51; DOI 10.1111/evj.12267_156

Weishaupt M. A., Waldern N. M., Amport C., Ramseier L. C., Wiestner T. (2013). Effects of shoeing on intra-and inter-limb coordination and movement consistency in Icelandic horses at walk, tölt and trot. Vet. J. 198, 109-1 13; DOI 10.1016/j.tvjl.2013.09.043

Wilson A. M., Seelig T. J., Shield R. A., Silverman B. W. (1998) The effect of foot imbalance on point of force application in the horse. Equine Vet. J. 30, 540-545; DOI 10.1111/i.2042-3306.1998. tb04531.x

Wright I. M. (1993) A study of 118 cases of navicular disease: clinical features. Equine Vet. J. 25, 488-492; DOI 10.1111/i.20423306.1993.tb02999.x 